\title{
Ichthyophonus-like infection in wild amphibians from Québec, Canada
}

\author{
Igor Mikaelian ${ }^{1, *}$, Martin Ouellet ${ }^{2}$, Bruce Pauli $^{3}$, Jean Rodrigue ${ }^{4}$, \\ John C. Harshbarger ${ }^{5}$, David M. Green ${ }^{2}$ \\ ${ }^{1}$ Canadian Cooperative Wildlife Health Centre and Centre Québécois sur la Santé des Animaux Sauvages, \\ 3200 rue Sicotte, Saint-Hyacinthe, Québec J2S 7C6, Canada \\ ${ }^{2}$ Redpath Museum, McGill University, 859 Sherbrooke St. West, Montréal, Québec H3A 2K6, Canada \\ ${ }^{3}$ Canadian Wildlife Service, National Wildlife Research Centre, 100 Boulevard Gamelin, Hull, Québec K1A 0H3, Canada \\ 'Service Canadien de la Faune, 1141 Route de l'Église, Sainte-Foy, Québec G1V 4H5, Canada \\ ${ }^{5}$ Registry of Tumors in Lower Animals, The George Washington University, Department of Pathology, 2300 I St. NW, \\ Washington, DC 20037, USA
}

\begin{abstract}
Myositis associated with infection by Ichthyophonus-like organisms was diagnosed in 35 of $260(13 \%)$ wild amphibians collected in Québec, Canada, from 1959 to $1964(\mathrm{n}=30)$, and 1992 to 1999 ( $n=230$ ). Infection was diagnosed in 17 green frogs Rana clamitans, 9 wood frogs $R$. sylvatica, 4 red-spotted newts Notophthalmus viridescens, 3 bullfrogs $R$. catesbeiana, 1 spring peeper Pseudacris crucifer, and 1 pickerel frog $R$. palustris. The spring peeper and one of the bullfrogs were collected in 1964 from the Mont Saint-Hilaire Biosphere Reserve, indicating long-term presence of the organism. Spores of the organisms invaded striated muscle fibers and were associated with variable degrees of granulomatous and eosinophilic inflammation. Infection was considered fatal in 2 green frogs, 1 wood frog, and 1 red-spotted newt. It was considered potentially significant in 3 additional green frogs in which up to $100 \%$ of the fibers of some muscles were replaced by spores associated with a severe granulomatous reaction. Ultrastructural features of Ichthyophonus-like spores included a thick trilaminated wall, a paramural cytoplasm, multiple nuclei, oval mitochondria with short tubulo-vesicular cristae and numerous ribosomes. This report represents 4 new host records and shows that ichthyophonosis is enzootic in amphibians from Québec.
\end{abstract}

KEY WORDS: Amphibian · Anuran · Eukaryotic protist · Ichthyophonosis · Pathology

\section{INTRODUCTION}

Some amphibian populations have declined dramatically in recent times, and some species have become extinct. Numerous causes have been proposed to account for these declines, including habitat loss (Delis et al. 1996), climatic changes (Pounds et al. 1999), use of pesticides and other agricultural chemicals (Bishop et al. 1999), increased UV-B irradiance (Blaustein et al. 1998), introduced species (Fisher \& Shaffer 1996), and disease (Berger et al. 1998)

\footnotetext{
- Present address: IDEXX Veterinary Services, 2825 Kovi Drive, West Sacramento, California 95605, USA.

E-mail: igor-mikaelian@idexx.com
}

Ichthyophonus hoferi has been reported to cause systemic granulomatous disease in more than 100 species of marine fish (McVicar 1982, Ragan et al. 1996). The species had been assigned to various taxonomic groups until it was grouped with Dermocystidium spp., Psorospermium spp., and the 'rosette agent' in an asyet-unnamed clade of eukaryotic protists which are parasites of aquatic animals (Ragan et al. 1996). Periodic outbreaks of ichthyophonosis have been reported in marine fish from cold and temperate waters of the Atlantic and Pacific oceans, and some of these outbreaks have been associated with declines in affected fish species (McVicar 1982, Mellergaard \& Spanggaard 1997, Marty et al. 1998).

The red-spotted newt Notophthalmus viridescens (Herman 1984, Green et al. 1995) and the bullfrog 
Rana catesbeiana (Goodchild 1953) are the only amphibian species in which Ichthyophonus-like infection has been reported. In these species, clinically infected animals had amyotrophy or prominent swellings on the body surface that occasionally evolved towards cutaneous ulceration. Ichthyophonus-like organisms were associated with granulomatous myositis in both species and, in bullfrogs, with the formation of large subcutaneous granulomas posterior to the sacrum region. In a lake in West Virginia, USA, the epizootic caused clinical signs in at least $10 \%$ of the red-spotted newts and was considered a likely mortality factor in the population (Herman 1984).

This report reviews cases of infection by Ichthyophonus-like organisms diagnosed in amphibians submitted to the Québec Region of the Canadian Cooperative Wildlife Health Centre. The study includes 35 amphibians belonging to 6 species, and represents 4 new host records.

\section{MATERIALS AND METHODS}

All amphibians examined were wild-caught specimens from the St. Lawrence River Valley of Québec, Canada. Altogether 131 amphibian submissions totalling 260 individuals representing 16 species were examined. Most specimens ( $n=230$ ) were collected from 1992 to 1999 as part of a research project aimed at assessing the health status of amphibians in Québec (Ouellet et al. 1997). In addition, 30 specimens, collected from 1959 to 1964, and deposited in the collection of the Redpath Museum, McGill University, Montréal, Québec, were examined. Seventeen rock bass Ambloplites rupestris were also collected from Dieppe pond at the Mont Saint-Hilaire Biosphere Reserve, where 2 green frogs Rana clamitans collected the same day had clinical infection by Ichthyophonus-like organisms; rock bass was the only fish species in the pond.

Live-collected amphibians were euthanized by an oral overdose of $20 \%$ benzocaine (Orajel, Del Pharmaceutics, Barrie, Ontario, Canada). The abdomen was incised and the specimen fixed whole in $10 \%$ buffered formalin. Fon malin-fixed specinens were cut in 3 to $4 \mathrm{~mm}$ thick transverse sections which were processed for histopathology. Paraffin-embedded tissues were sectioned at $5 \mu \mathrm{m}$, and stained with haematoxylinphloxine-saffron. Sections presenting Ichthyophonuslike elements were stained with periodic-acid Schiff (PAS) and Grocott's methenamine silver nitrate (GMS). Muscle samples of a red-spotted newt with acute severe myositis associated with Ichthyophonus-like organisms were processed for transmission electron microscopy
Muscles of 2 green frogs and a red-spotted newt with severe acute infection by Ichthyophonus-like organisms were kept at room temperature to allow for germination of the spores (McVicar 1982). Squash preparations of these tissues were examined daily for $4 \mathrm{~d}$.

To assay infectivity of Ichthyophonus-like organisms, muscle homogenates and minced muscles of a green frog with acute severe infection were used to inoculate goldfish Carassius auratus purchased at a local pet shop. Fish were housed in a $30 \mathrm{l}$ aquarium and fed daily with a commercial diet (Tropical Flakes, Wardley, Secaucus, NJ, USA). One goldfish was inoculated intraperitoneally with $1 \mathrm{ml}$ of muscle homogenate made of $0.5 \mathrm{~g}$ affected muscle and $0.75 \mathrm{ml}$ of $0.9 \%$ saline. Another goldfish was inoculated intramuscularly with an identical inoculum. Three other goldfish were offered and readily ate about $0.5 \mathrm{~g}$ each of minced muscle from the same green frog. Fish were kept for $9 \mathrm{~d}$ following inoculation or exposure, euthanized by cervical section and processed as described above.

\section{RESULTS}

Ichthyophonus-like spores were associated with myositis in 17 green frogs, 9 wood frogs Rana sylvatica, 4 red-spotted newts, 3 bullfrogs, 1 spring peeper Pseudacris crucifer, and 1 pickerel frog $R$. palustris (Table 1). The spring peeper and 1 bullfrog were collected in 1964 while all other cases were from the 1990s. Most amphibians (136 of 260 individuals) originated from the Mont Saint-Hilaire Biosphere Reserve

Table 1. Prevalence of Ichthyophonus-like myositis in amphibians from Québec, 1959 to 1999

\begin{tabular}{lc}
\hline Host & No. infected/no, examined $(\%)$ \\
\hline Green frog & $17 / 83(20)$ \\
Wood frog & $9 / 39(23)$ \\
Red-spotted newt & $4 / 20(20)$ \\
Bullfrog & $3 / 11(27)$ \\
Pickerel frog & $1 / 3(33)$ \\
Spring peeper & $1 / 4(25)$ \\
Other species & $0 / 100(0)$ \\
Total & $35 / 260(13)$ \\
& \\
a 100 specimens belonging to 10 other species were exam- \\
ined: 33 northern leopard frogs Rana pipiens, 26 Amer- \\
can toads Bufo americanus, 11 redback salamanders \\
Plethodon cinereus, 8 western chorus frogs Pseudacris \\
triseriata, 7 mink frogs $R$. septentrionalis, 6 blue-spotted \\
salamanders Ambystoma laterale, 4 gray treefrogs Hyla \\
versicolor, 3 spotted salamanders A. maculatum, 1 mud- \\
puppy Necturus maculosus, and 1 northern dusky sala- \\
mander Desmognathus fuscus
\end{tabular}


$\left(45^{\circ} 33^{\prime} \mathrm{N}, 73^{\circ} 10^{\prime} \mathrm{W}\right)$, near Montréal, Québec; all but 3 cases of Ichthyophonus-like infection were diagnosed at this site. These 3 cases were 2 bullfrogs at Lac Clara $\left(46^{\circ} 53^{\prime} \mathrm{N}, 73^{\circ} 08^{\prime} \mathrm{W}\right)$, and 1 green frog at Lac Memphrémagog $\left(45^{\circ} 09^{\prime} \mathrm{N}, 72^{\circ} 16^{\prime} \mathrm{W}\right)$. Amphibians $(\mathrm{n}=116)$ at the other 20 collection sites were free of Ichthyophonus-like organisms (Table 1).

Ichthyophonus-like organisms were restricted to skeletal striated muscles in most cases. Rarely, a small number of spores infected the subcutis. The severity of infection was variable among individuals (Table 2) and from one muscle to the other. No specific muscle or group of muscles was consistently affected.

Two types of Ichthyophonus-like spores were found: active spores and passive spores. Both spores were round to oval. Active spores were large, measuring from 100 to $220 \mu \mathrm{m}$ in diameter, and were located within the sarcoplasm of skeletal muscle fibers (Fig. 1). They had a thin smooth wall. They contained numerous and evenly distributed nuclei surrounded by a thin clear halo enmeshed within a foamy material that stained pale red with PAS, indicating the presence of polysaccharides.

Passive spores were smaller, measuring 40 to $100 \mu \mathrm{m}$ in diameter, and were found in the endomysium, the perimysium, the epimysium and, rarely, in the subcutis (Fig. 2). Passive spores were surrounded by a thick triple-contoured wall, up to $12 \mu \mathrm{m}$ in thickness. This wall consisted of a thick hyaline portion surrounded by a thin acidophilic layer on the inner side, and by a

Table 2. Ichthyophonus-like myositis in amphibians from Québec. Type of spores: (a) active; (p) passive

\begin{tabular}{|c|c|c|c|c|c|c|c|}
\hline Species & Stage & Date & $\begin{array}{l}\text { Reason for } \\
\text { submission }\end{array}$ & $\begin{array}{l}\text { Affected/ } \\
\text { examined }\end{array}$ & $\begin{array}{l}\% \text { muscle } \\
\text { fibers } \\
\text { affected }^{a}\end{array}$ & $\begin{array}{l}\text { Type of } \\
\text { spores }\end{array}$ & Diagnosis \\
\hline Bullfrog & Juvenile & May 1964 & $\begin{array}{l}\text { Museum } \\
\text { specimen }\end{array}$ & $1 / 1$ & $<1$ & $\mathrm{p}$ & Minimal granulomatous myositis \\
\hline Bullfrog & $\begin{array}{c}\text { Tadpole } \\
\text { and juvenile }\end{array}$ & Aug 1992 & Die-off & $2 / 7$ & 20 & $\mathrm{p}$ & Mild granulomatous myositis \\
\hline Green frog & Tadpole & Jun 1998 & Die-off & $1 / 2$ & $<1$ & $\mathrm{p}$ & Minimal granulomatous myositis \\
\hline Green frog & Juvenile & Jun 1998 & $\begin{array}{l}\text { Health } \\
\text { assessment }\end{array}$ & $1 / 1$ & 50 & $\mathrm{p}$ & $\begin{array}{l}\text { Mild to marked granulomatous myo- } \\
\text { sitis, unilateral traumatic enucleation }\end{array}$ \\
\hline Green frog & Juvenile & May 1999 & $\begin{array}{l}\text { Health } \\
\text { assessment }\end{array}$ & $2 / 5$ & $<1$ to 30 & $a, p$ & $\begin{array}{l}\text { Mild to moderate granulomatous and } \\
\text { eosinophilic myositis }\end{array}$ \\
\hline Green frog & $\begin{array}{l}\text { Juvenile } \\
\text { and adult }\end{array}$ & May 1999 & $\begin{array}{l}\text { Health } \\
\text { assessment }\end{array}$ & $11 / 23$ & $<1$ to 100 & $a, p$ & $\begin{array}{l}\text { Mild to severe granulomatous and } \\
\text { eosinophilic myositis }\end{array}$ \\
\hline Green frog & Adult & May 1999 & Moribund & $2 / 2$ & 100 & $\mathrm{a}, \mathrm{p}$ & $\begin{array}{l}\text { Severe granulomatous and eosino- } \\
\text { philic myositis }\end{array}$ \\
\hline Pickerel frog & Adult & Jun 1998 & Moribund & $1 / 1$ & $<1$ & $\mathrm{p}$ & $\begin{array}{l}\text { Gastric impaction by pine needles, } \\
\text { minimal granulomatous myositis }\end{array}$ \\
\hline $\begin{array}{l}\text { Red-spotted } \\
\text { newt }\end{array}$ & Adult & Jun 1997 & $\begin{array}{l}\text { Health } \\
\text { assessment }\end{array}$ & $1 / 1$ & $<1$ & $\mathrm{p}$ & Minimal granulomatous myositis \\
\hline $\begin{array}{l}\text { Red-spotted } \\
\text { newt }\end{array}$ & Adult & May 1998 & Moribund & $1 / 1$ & 10 & $\mathrm{p}$ & $\begin{array}{l}\text { Severe intestinal cestodiasis, severe } \\
\text { blood infection by Aegyptianella } \\
\text { ranarum, mild granulomatous myositis }\end{array}$ \\
\hline $\begin{array}{l}\text { Red-spotted } \\
\text { newt }\end{array}$ & Adult & Aug 1998 & $\begin{array}{l}\text { Deformities }(2 / 3) \\
\text { health assess- } \\
\text { ment }(1 / 3)\end{array}$ & $1 / 3$ & $<1$ & $\mathrm{p}$ & $\begin{array}{l}\text { Traumatic microphthalmia (1), syndac- } \\
\text { tyly (1), mild granulomatous myositis }\end{array}$ \\
\hline $\begin{array}{l}\text { Red-spotted } \\
\text { newt }\end{array}$ & Adult & Jun 1999 & Moribund & $1 / 1$ & 80 & $\mathrm{a}, \mathrm{p}$ & $\begin{array}{l}\text { Severe granulomatous and eosino- } \\
\text { philic myositis }\end{array}$ \\
\hline $\begin{array}{l}\text { Spring } \\
\text { peeper }\end{array}$ & Adult & Apr 1964 & $\begin{array}{l}\text { Museum } \\
\text { specimens }\end{array}$ & $1 / 2$ & 10 & $\mathrm{p}$ & Mild granulomatous myositis \\
\hline Wood frog & Adult & Jun 1998 & Moribund & $1 / 1$ & 80 & $a, p$ & $\begin{array}{l}\text { Severe granulomatous and eosino- } \\
\text { philic myositis }\end{array}$ \\
\hline Wood frog & Juvenile & Jul 1998 & Deformity & $1 / 1$ & $<1$ & $\mathrm{p}$ & $\begin{array}{l}\text { Microphthalmia, minimal granuloma- } \\
\text { tous myositis }\end{array}$ \\
\hline Wood frog & Juvenile & Jul 1998 & $\begin{array}{l}\text { Health } \\
\text { assessment }\end{array}$ & $7 / 8$ & $<1$ to 10 & $\mathrm{p}$ & $\begin{array}{l}\text { Minimal to mild granulomatous } \\
\text { myositis }\end{array}$ \\
\hline
\end{tabular}




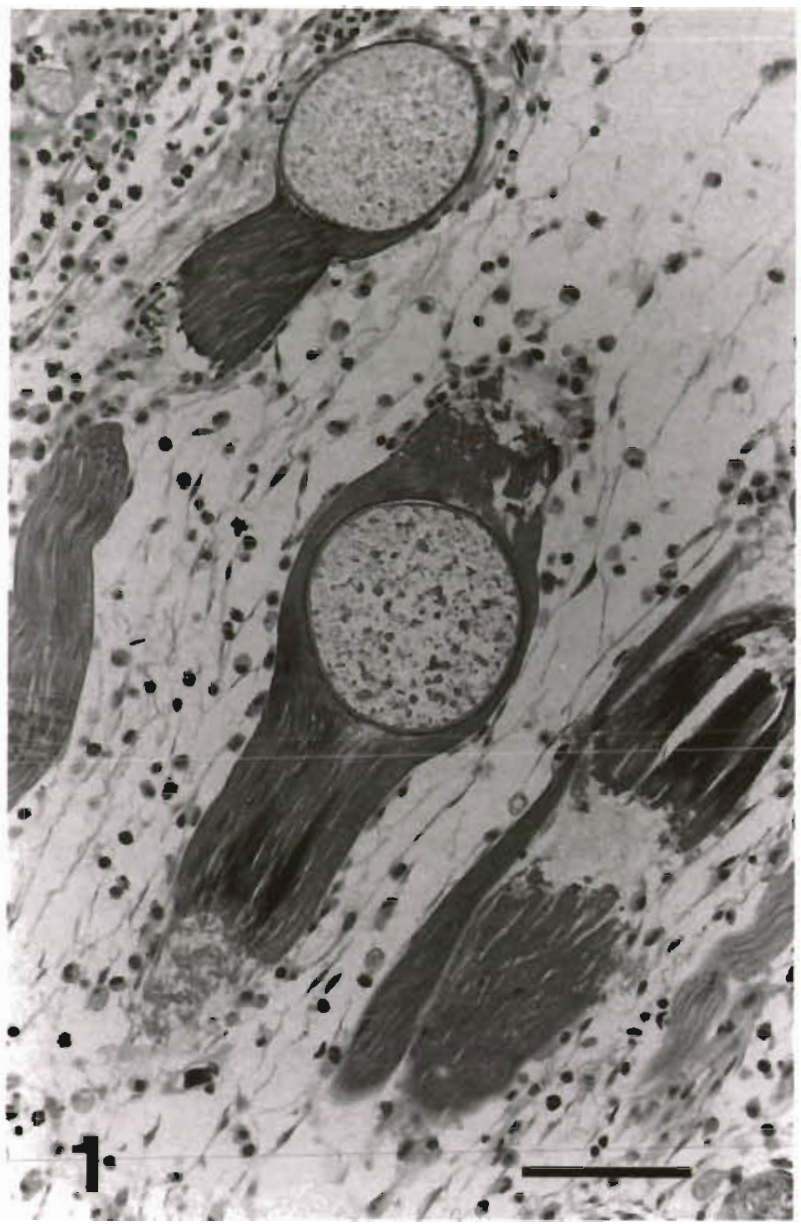

Fig. 1. Ichthyophonus-like infection. Active spore located in the sarcoplasm of a necrotic muscle fiber of a green frog Rana clamitans. The capsule of the spore is thin and the parasitized muscle fiber is necrotic. The endomysium shows marked edema, and moderate histiocytic and eosinophilic infiltration.

Haematoxylin-phloxine-saffron. Scale bar $=100 \mu \mathrm{m}$

coarsely wrinkled eosinophilic layer on the outer side. The cytoplasm was delicately granular and acidophilic, and stained brightly acidophilic with PAS, indicating the presence of large amounts of polysaccharides. Other microscopic characteristics of passive spores were similar to those of active spores. Representative histologic sections of green frogs with Ichthyophonus infection were deposited at the Registry of Tumors in Lower Animals (RTLA 6898-6904).

IChthyophonus-like infection was associated with severe clinical signs in 2 green frogs, 1 wood frog, and 1 red-spotted newt (Table 2). Clinical signs included lethargy $(4 / 4)$, reluctance $(1 / 4)$ or inability $(3 / 4)$ to move, and amyotrophy (1/4). From 80 to $100 \%$ of the fibers of most muscles of these amphibians were replaced by Ichthyophonus-like active spores surrounded by a moderate to severe diffuse granuloma- tous and eosinophilic myositis associated with variable degrees of edema (Fig. 3). A variable number of passive spores were also present.

The 2 green frogs with clinical infection originated from Dieppe pond in the Mont Saint-Hilaire Biosphere Reserve and were captured a few hours apart. Examination of 23 other green frogs captured the same day at this pond showed that 11 of them were infected by Ichthyophonus-like organisms. Infection was considered to be active in 3 of these frogs, consisting of active spores associated with a severe granulomatous myositis in several muscles. Infection was limited to the presence of passive spores in the remaining 8 infected frogs, although some muscles of these were totally replaced by spores. Ichthyophonus-like organisms were absent from all tissue sections of 17 rock bass collected from this pond.

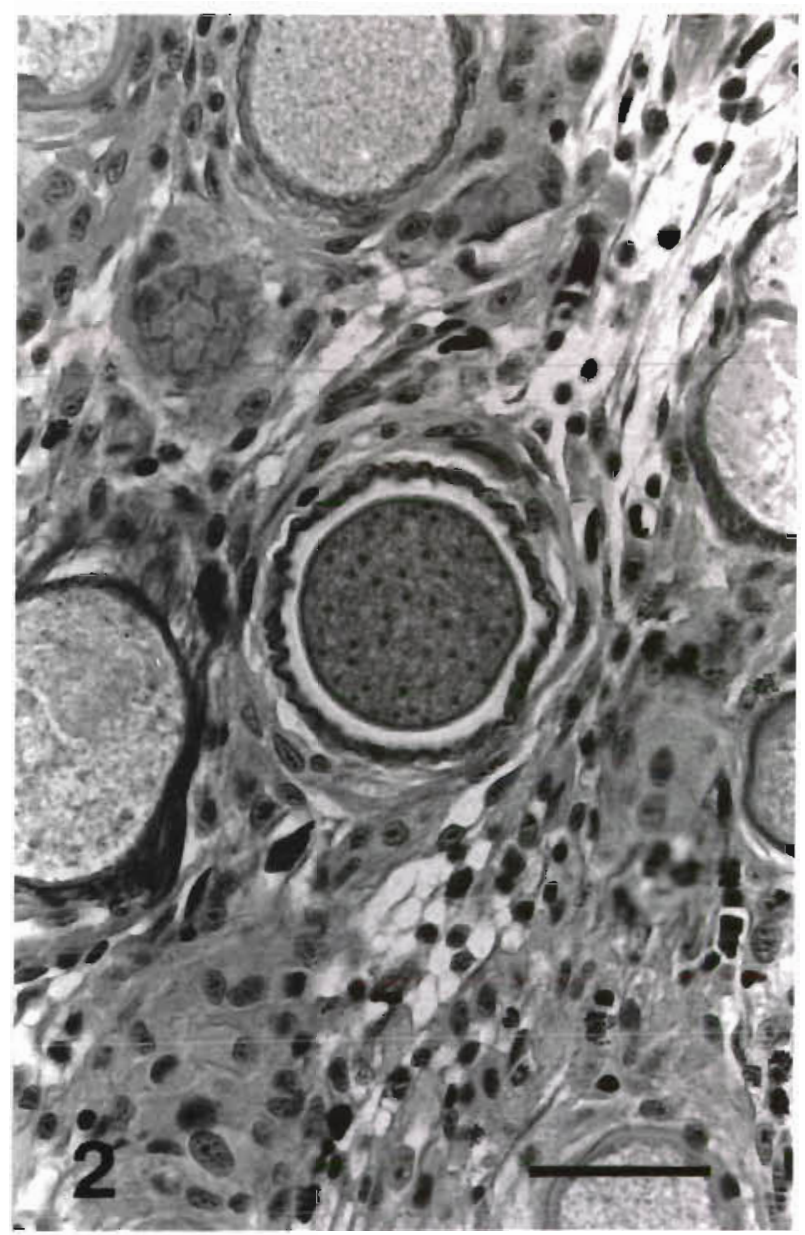

Fig. 2. Ichthyophonus-like infection. Passive spore is located in the epimysium of a green frog Rana clamitans. The capsule of the spore is thick with a wrinkled outer layer. Infection is associated with a marked granulomatous reaction which has totally effaced the architecture of the tissue. Haematoxylinphloxine-saffron. Scale bar $=25 \mu \mathrm{m}$ 


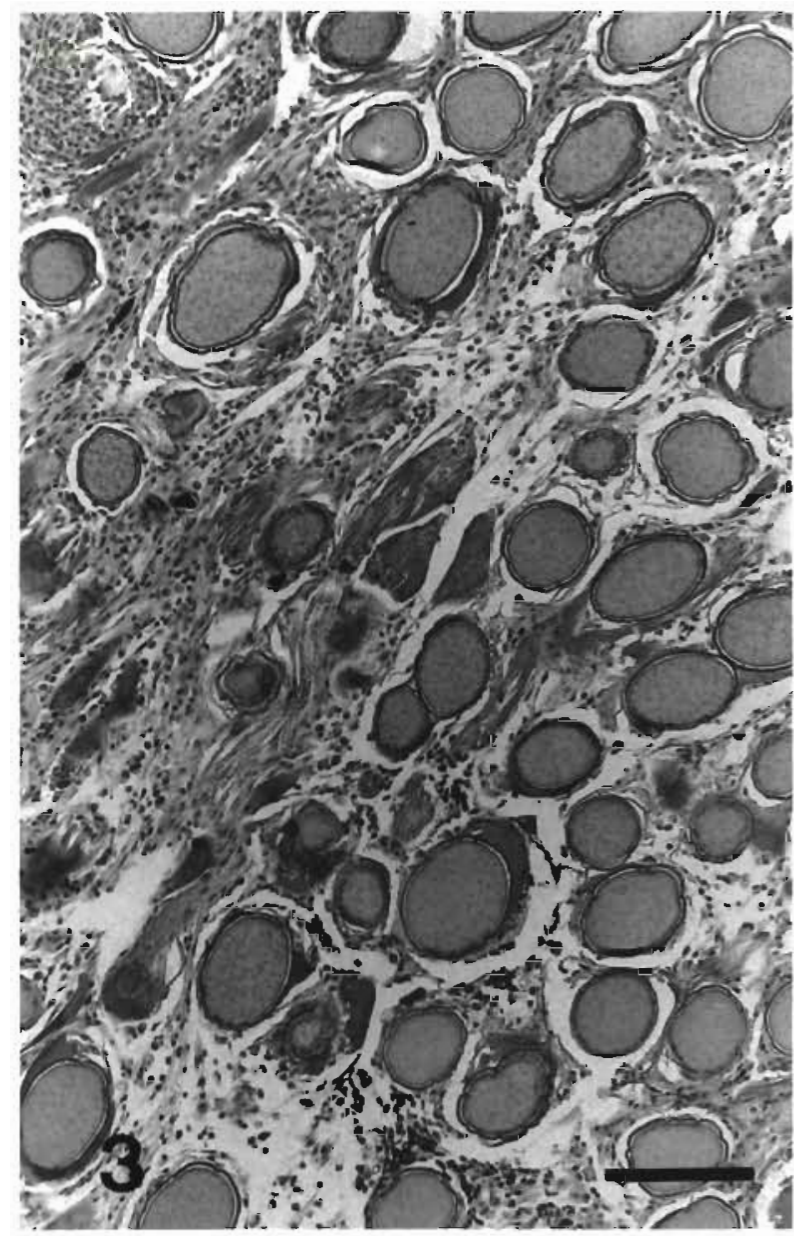

Fig. 3. Ichthyophonus-like infection of the muscles of a wood frog Rana sylvatica is associated with severe granulomatous inflammation. The spores are predominantly active spores, but the capsule of a few spores is slightly wrinkled, indicating maturation to passive spores. Haematoxylin-phloxine-saffron Scale bar $=150 \mu \mathrm{m}$

Infection with passive spores of Ichthyophonus-like organisms not associated with clinical signs was diagnosed in 8 wood frogs, 3 red-spotted newts, 4 green frogs (separate from those mentioned above), 3 bullfrogs, 1 spring peeper, and 1 pickerel frog (Table 2). Most of the spores were surrounded by a thick fibrous capsule with a few macrophages and many of them were degenerated.

Ultrastructurally, active spores were delineated by a thick trilaminated wall consisting of 2 electron-lucent layers separated by a thin electron-dense layer (Fig. 4). The outer electron-lucent layer was made of parallel and long fibrils without periodicity orientated perpendicularly to the wall of the spore, with a few membrane-bound vesicles and glycogen granules. The intermediate electron-dense layer was amorphous. The inner layer was made of short branching fibrils that were haphazardly distributed. Immediately under the inner layer of the wall, there was an undulant plasmalemma lined by a continuous band of paramural cytoplasm where most mitochondria were located. Mitochondria were oval and had a few short tubulovesicular cristae. Organelles included numerous ribosomes, a moderate amount of rough endoplasmic reticulum, and a few arrays of smooth endoplasmic reticulum, lysosomes, and multi-vesicular bodies (Fig. 5). A few lipid droplets and glycogen bodies were also present. Nuclei were evenly distributed within the cytoplasm, were oval to polygonal, and had a large central nucleolus. Dictyosomes were absent. Passive spores were not available for ultrastructural examination.

Squash preparations of the muscles of 2 green frogs and 1 red-spotted newt kept for $4 \mathrm{~d}$ at room temperature failed to demonstrate germination or hyphae formation.

Goldfish inoculated with Ichthyophonus-like organisms remained apparently healthy. They were euthanized $9 \mathrm{~d}$ after inoculation. All tissue sections from these fish were free of lesions and of Ichthyophonuslike organisms.

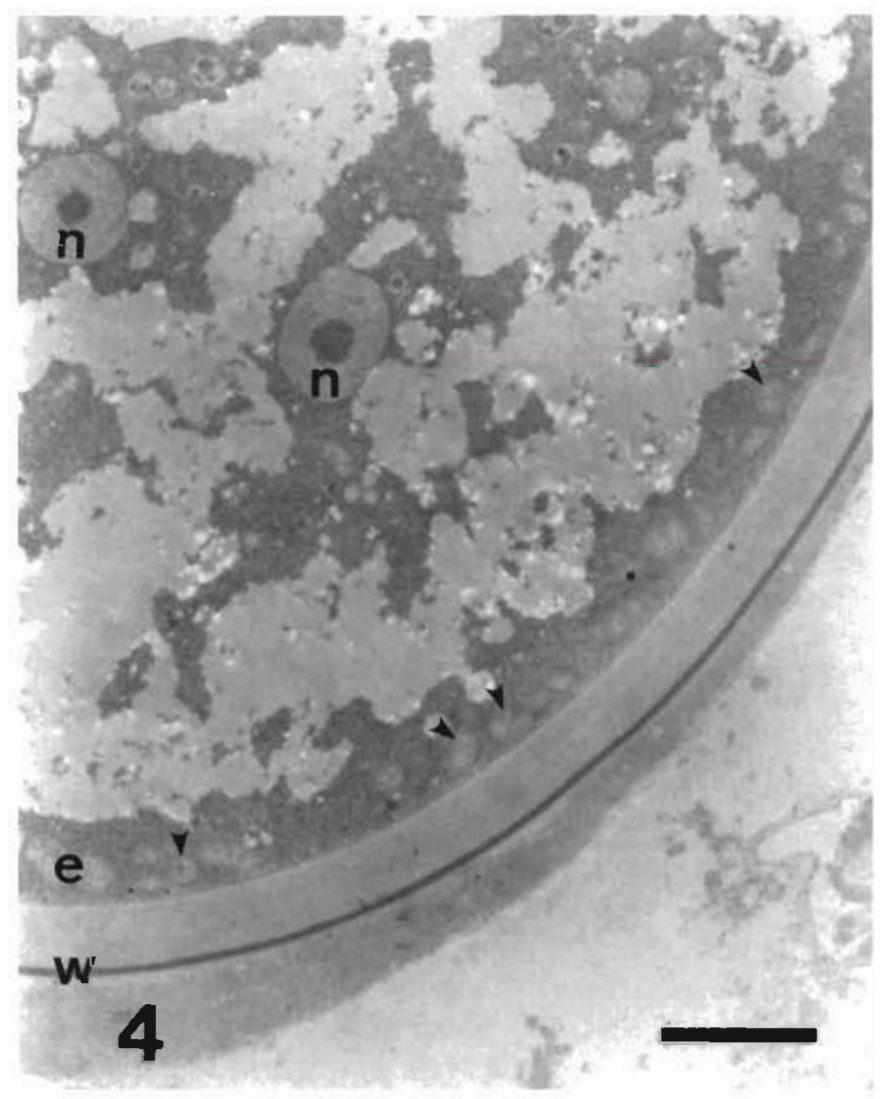

Fig. 4. Ichthyophonus-like infection. Low magnification ultrastructure of an active spore from the muscles of a red-spotted newt Notophthalmus viridescens. The wall $(w)$ of the spore is trilaminated. Immediately under the wall, there is a thin band of paramural endoplasm (e) where most mitochondria (arrowheads) are localized. n: nuclei. Scale bar $=4 \mu \mathrm{m}$ 


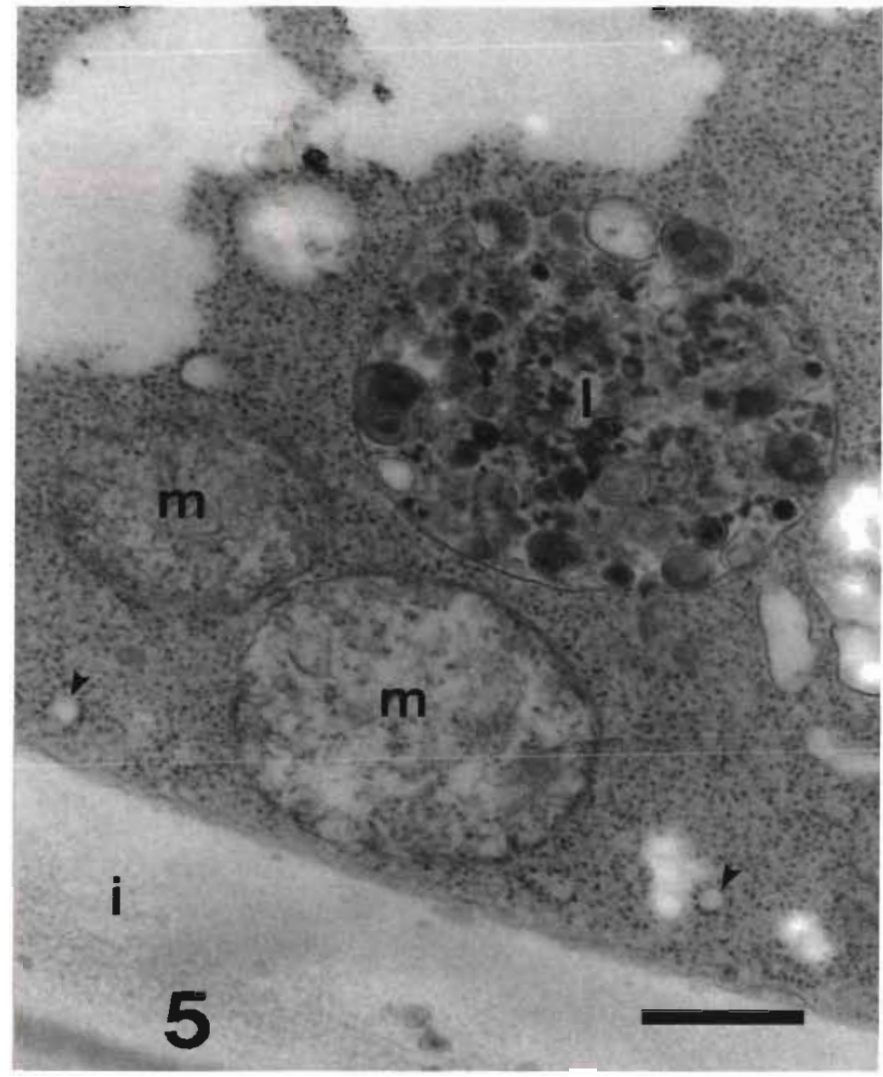

Fig. 5. Ichthyophonus-like infection. High magnification ultrastructure of an active spore from the muscles of a red-spotted newt Notophthalmus viridescens. The paramural cytoplasm contains numerous ribosomes. Other organelles include arrays of rough endoplasmic reticulum (arrowheads), dilated smooth endoplasmic reticulum, mitochondria (m), and a large lysosome (l). i: inner portion of the wall. Scale bar $=500 \mathrm{~nm}$

\section{DISCUSSION}

Histological and ultrastructural characteristics of Ichthyophonus-like organisms of amphibians observed in the present study show that these organisms are closely related to $I$. hoferi of fish. However, infection of amphibians with Ichthyophonus-like organisms differs from ichthyophonosis in fish in that: (1) germination and hyphae formation could not be obtained in skeletal muscles of dead amphibians while I. hoferi germination and hyphae formation in fish tissues occurs within 15 to $30 \mathrm{~min}$ of host death (McVicar 1982); (2) the skeletal muscle was the only tissue affected in amphibians while $I$. hoferi may parasitize all tissues in fish (Rand 1994, Patterson 1996, Mellergaard \& Spanggaard 1997, Marty et al. 1998, Rahimian 1998) (3) spores from the red-spotted newt lacked dictyosomes while these structures are common in $I$. hoferi spores (Rahimian 1998); (4) experimental transmission of Ichthyophonus-like infection could not be achieved with goldfish while fish are readily infected by $I$. hoferi administered orally (McVicar 1982) or intraperitoneally (Rand \& Cone 1990); (5) rock bass sharing the pond of green frogs affected by an epizootic of Ichthyophonus-like infection remained uninfected. Taken together, these observations suggest that Ichthyophonus-like organisms infecting amphibians may represent a species distinct from I. hoferi. Molecular methods are needed to investigate this point.

Ichthyophonus-like organisms in amphibians from the present report and from previously described cases (Goodchild 1953, Herman 1984, Green et al. 1995) can be differentiated from thick-walled fungi such as $R h i-$ nosporidium seeberi and Chrysosporium spp. R. seeberi differs from Ichthyophonus-like organisms of amphibians in that infection is limited to the upper respiratory tract of humans and animals, is characterized by trophic forms and sporangia, and contains endospores (Chandler et al. 1980). Chrysosporium spp. differ from Ichthyophonus-like organisms in that they have adiaspores which have a $24 \mu \mathrm{m}$ thick wall and lack multiple nuclei (Chandler et al. 1980).

Ichthyophonus hoferi has a low host specificity (McVicar 1982, Rand \& Cone 1990, Rahimian 1998). Similarly, Ichthyophonus-like organisms affecting amphibians may have a low host specificity because of their wide range of hosts and geographic distribution (Herman 1984, Green et al. 1995). The life-cycle of $I$. hoferi in fish involves ingestion of the organism from the infected tissues of a prey item, followed by invasion of the gastric mucosa and vessels, and dissemination to multiple organs (McVicar 1982). It is likely that a prey item may be involved in maintenance of the organism in amphibians but this host is unknown at this time. From the present study, however, freshwater fish would seem to be an unlikely route of transmission.

The finding of a high prevalence of infection by Ichthyophonus-like organisms in apparently healthy green frogs in a pond where 2 frogs had clinical disease suggests that Ichthyophonus-like epizootics may have passed unnoticed in the past, and that fatal infection with this organism may be common. Animals with clinically significant infection may be more vulnerable to predation and, therefore, less likely to be collected during sampling programs than less severely affected individuals. However, without further investigation of the incidence and severity of infection by Ichthyophonus-like organisms in wild amphibians, the significance of this disease as a mortality factor in local populations remains unknown.

In 28 of the 35 cases presented here, infection by Ichthyophonus-like organisms was considered an incidental finding. In these cases, many spores were degenerated and all were surrounded by a thick 
fibrous capsule, suggesting that infection by Ichthyophonus-like organisms can be a self-limiting disease. The factors accounting for the development of clinically significant infection by IChthyophonus-like organisms in amphibians and $I$. hoferi in fish (Patterson 1996, Rahimian \& Thulin 1996, Mellergaard \& Spanggaard 1997, Marty et al. 1998) remain undetermined.

Acknowledgements. We are grateful to J. Bonin, P. Labonté, M. Lieutenant-Gosselin, L. Paetow, R. Pétel, and M. Trudel for field assistance, and to J. Cardin, J. Deslandes, C. Lussier, L. Pépin, and B. Pépin-Faille for laboratory assistance. This study was funded by the Canadian Cooperative Wildlife Health Centre, Saskatoon, Saskatchewan, by the Centre Québécois sur la Santé des Animaux Sauvages, SaintHyacinthe, Québec, by the National Wildlife Research Center of the Canadian Wildlife Service, Hull, Québec, by the Service canadien de la faune, Sainte-Foy, Québec, Québec, and by the Toxic Substances Research Initiative, Government of Canada. The Registry of Tumors in Lower Animals is supported by National Cancer Institute Contract NO1-CB-77021 supplemented by The National Institute of Environmental Health Sciences. We also thank the Gault Estate of McGill University for providing the opportunity to sample specimens at the Mont Saint-Hilaire Biosphere Reserve.

\section{LITERATURE CITED}

Berger L, Speare R, Daszak P, Green DE, Cunningham AA, Goggin CL, Slocombe R, Ragan MA, Hyatt AD, McDonald KR, Hines HB, Lips KR, Marantelli G, Parkes H (1998) Chytridiomycosis causes amphibian mortality associated with population declines in the rain forests of Australia and Central America. Proc Natl Acad Sci USA 95: 9031-9036

Bishop CA, Mahony NA, Struger J, Ng P, Pettit KE (1999) Anuran development, density and diversity in relation to agricultural activity in the Holland river watershed, Ontario, Canada (1990-1992). Environ Monit Assess 57: $21-43$

Blaustein AR, Kiesecker JM, Chivers DP, Hokit DG, Marco A, Belden LK, Hatch A (1998) Effects of ultraviolet radiation on amphibians: field experiments. Am Zool 38:799-812

Chandler FW, Kaplan W, Ajello L (1980) A colour atlas and textbook of the histopathology of mycotic diseases. Wolfe Medical Publications, London

Delis PR, Mushinsky HR, McCoy ED (1996) Decline of some west-central Florida anuran populations in response to habitat degradation. Biodivers Conserv 5:1579-1595

Fisher RN, Shaffer HB (1996) The decline of amphibians in

Editorial responsibility: Peernel Zwart,

Utrecht, The Netherlands
California's Great Central Valley. Conserv Biol 10: $1387-1397$

Goodchild CG (1953) A subcutaneous, cyst-parasite of bullfrogs: Histocystidium ranae, n.g., n.sp. J Parasitol 39: $395-405$

Green DE, Andrews J, Abell JM (1995) Preliminary investigations on a mycotic myositis in red-spotted newts (Notophthalmus $v$. viridescens) from Vermont. In: Zwart $\mathrm{P}$, Matz G (eds) Cinquième Colloque International de Pathologie des Reptiles et des Amphibiens. Alphen Aan den Rijn, The Netherlands, p 51-62

Herman RL (1984) Ichthyophonus-like infection in newts (Notophthalmus viridescens Rafinesque). J Wildl Dis 20: $55-56$

Marty GD, Freiberg EF, Meyers TR, Wilcock J, Farver TB, Hinton DE (1998) Viral hemorrhagic septicemia virus, Ichthyophonus hoferi, and other causes of morbidity in Pacific herring Clupea pallasi spawning in Prince William Sound, Alaska, USA. Dis Aquat Org 32:15-40

McVicar AH (1982) Ichthyophonus infection of fish. In: Roberts RJ (ed) Microbial diseases of fish. Academic Press, London, p 243-269

Mellergaard S, Spanggaard B (1997) An Ichthyophonus hoferi epizootic in herring in the North Sea, the Skagerrak, the Kattegat and the Baltic Sea. Dis Aquat Org 28:191-199

Ouellet M, Bonin J, Rodrigue J, DesGranges JL, Lair S (1997) Hindlimb deformities (ectromelia, ectrodactyly) in freeliving anurans from agricultural habitats. J Wildl Dis 33: 95-104

Patterson KR (1996) Modelling the impact of disease-induced mortality in an exploited population: the outbreak of the fungal parasite Ichthyophonus hoferi in the North Sea herring (Clupea harengus). Can J Fish Aquat Sci 53: 2870-2887

Pounds JA, Fogden MPL, Campbell JH (1999) Biological response to climate change on a tropical mountain. Nature 398:611-615

Ragan MA, Goggins CL, Cawthorn RJ, Cerenius L, Jamieson AVC, Plourde SM, Rand TG, Söderhäll K, Gutell RR (1996) A novel clade of protistan parasites near the animal-fungal divergence. Proc Natl Acad Sci USA 93:11907-11912

Rahimian H (1998) Pathology and morphology of Ichthyophonus hofen in naturally infected fishes off the Swedish west coast. Dis Aquat Org 34:109-123

Rahimian H. Thulin J (1996) Epizootiology of Ichthyophonus hoferi in herring populations of the Swedish west coast. Dis Aquat Org 27:187-195

Rand TG (1994) An unusual form of Ichthyophonus hoferi (Ichthyophonales: Ichthyophonaceae) from yellowtail flounder Limanda ferruginea from the Nova Scotia shelf. Dis Aquat Org 18:21-28

Rand TG, Cone DK (1990) Effects of Ichthyophonus hoferi on condition indices and blood chemistry of experimentally infected rainbow trout (Oncorhynchus mykiss). J Wildl Dis $26: 323-328$

Submitted: October 28, 1999; Accepted: November 19, 1999 Proofs received from author(s): March 10, 2000 